\title{
STUDIES ON SOME MEDICINAL PLANT EXTRACTS AS IMMUNOSTIMULANT IN RATS EXPERIMENTALLY INFECTED WITH SALMONELLA TYPHIMURIUM
}

\author{
ROFAIIL, S.K. ${ }^{1}$, RAGAA A.SOLIMAN ${ }^{2}$, OLA F. ABO-ELMENEM ${ }^{2}$ \\ AND M.H., MAHMOUD ${ }^{1}$
}

1. Veterinary Serum and Vaccine Research Institute, ARC, Ministry of Agriculture, Dokki, Giza

2. Animal Health Research Institute, ARC, Ministry of Agriculture, Dokki, Giza

(Manuscript received 3 November 2010 )

\begin{abstract}
Aloe extract was used as diet supplementation in a group of rats experimentally infected with Salmonella typhimurium. It was found that rats that fed on diet with aloes extract for 30 days, then, experimentally infected with Salmonella typhimurium showed survival rate $92 \%$ in comparison with group of rats fed on ration without aloes extract and experimentally infected with Salmonella typhimurium. Histopathological examination revealed that treated group with rats of aloes extract showed few histopathological changes, while those non-treated group showed significant infiltration of liver with mature and premature leucocytic cells in hepatic tissues with severe necrotic changes. Moreover, the heart of such untreated group with aloes extract showed leucocytic inflammatory cells infiltration between the bundles of degenerated cardiac muscles.
\end{abstract}

\section{INTRODUCTION}

Aloes is a herb native to the Mediterranean. The active principle of aloes was found to inhibit the growth of several species of pathogenic bacteria, and also, has a beneficial effect on the immune system (Harborne et al., 1999).

Salmonella typhimurium is one of the most important bacteria causing disease condition and high mortalities, in which the immune status deficiency plays an important role in the incidence and progress of the bacteria (Harkness and Wagner, 1995 and Rofaiil, 2001). Furthermore, the possibility of preventing the disease using some dietary supplements and/or herbal medicine has attracted considerable attention (Hassan et al., 2008).

Many drugs and chemicals can enhance various aspects of the immune response, immunopotentiation may occur by increasing the rate at which the immune response develops, the intensity level of the response and prolongation of the response or development of response to another more non-immunogenic substances (Rofaiil et al., 2007). Interest is arising in the possible use of plant extracts as a source of naturally occurring antibiotic like substance (Aisha, 1987 and Rofaiil and Daoud, 2005). 
Little effort was done on investigation of the role played by aloe extract to enhance its the therapeutic effect for controlling some infection (Laurnert, 1981).

So, the aim of the present study was to throw light on the possible role of aloes extract as a protecting agent in rats experimentally infected with Salmonella typhimurium.

\section{MATERIALS AND METHODS}

\section{Aloes extract}

It was obtained as powder from Faculty of Pharmacy, mixed as $2.5 \%$ with basal ration of experimental rats.

\section{Ration}

A balanced ration consumed by the experimental rats was examined bacteriologically and proved to be free from Salmonella.

\section{Experimental rats}

One hundred and fifty healthy rats were kept in separated cages under strict hygienic conditions during the experiment.

\section{Salmonella typhimurium strain}

Local isolate of Salmonella typhimurium used in the present study was identified through Gram staining, colonial morphology, biochemical and serological reactions as described by Forbes et al. (1998).

\section{Experimental Design}

Experimental rats with age of 30 days, and weight of $100 \mathrm{gm}$ were divided into 3 groups, (50 rats each) as follows:

Group (1): Rats were fed on ration supplemented with aloes extract for a period of 30 days.

Groups (2 and 3): Rats were fed on ration without aloes extract supplementation for a period of 30 day.

At the end of the 30 day both groups (1) and (2) were experimentally injected peritoneally with $0.5 \mathrm{ml}$ of twenty-four hours broth culture of Salmonella typhimurium containing $1.5 \times 10^{8} \mathrm{CFU} / \mathrm{ml}$. Such rats were observed daily after experimental infection, and mortalities were recorded. Smears from internal organs of freshly dead rat were subjected to bacteriological examination for reisolation of the organism. Reisolation of the organism was done as described by Forbes et al. (1998). The rats of group (3) were left as negative control.

For histopathological examination, tissue samples from the liver and heart of dead rats post-experimental infection were collected and fixed in $10 \%$ neutral formalin, washed by tape water, dehydrated in graded ethanol, embedded in paraffin, 
sectioned at 4-5 microns and stained by hematoxylin and eosin following the standard technique of Bancroft et al. (1994).

\section{RESULTS AND DISCUSSION}

This work has been designed to investigate the protective effect of aloes extract supplementation on the ration of rats against artificial infection with Salmonella typhimurium.

Aloes is a herb that was reported to have an immunostimulant effect. The extract of such plant contained several ingredients with potential value. It is composed of glucosides as aloin, sabarin and paraolin, organic acids as simanec. Also, it contains Amadin and anthradion (Mueller et al., 1999).

Data recorded in Table 1 showed that protective effect of aloe extract supplementation in ration of rats experimentally infected with Salmonella typhimurium, the survival percentage among such treated group with aloe extract was recorded $92 \%$, with a mean death time of 7 days, and a mean lesion score $(+)$ (slight congestion). Meanwhile, in non-treated group, the survival percentage was $20 \%$ with a mean death time of 3 days and a mean lesion score $(+++)$ (severe congestion and petechial hemorrhage). It could be stated that the action of aloe extract in reducing the mortality rate of rats infected with Salmonella typhimurium is due to its properties as anti-microbial agent (Laurnert, 1981) and immunostimulant effect (Mueller et al., 1999).

From the obtained results, the anti-microbial response producing by aloe extract is similar to that reported by Benirsckle et al. (1978) and James et al. (2002) who explained that the improvement of the immune status of rats is due to the enhancement of the natural killer cells to restore their activity.

From the pathological point of view, the group of rats that fed on ration supplemented with aloe extract can resist the intraperitoneal inoculation with Salmonella typhimurium. They appeared nearly normal macroscopically and microscopically, the internal organs specially liver and heart showed few pathological changes (Fig. 1 and 2). On the other hand, the rats fed on normal ration showed friable liver with focal necrosis and congestion. The liver showed mature and premature leucocytic cells infiltration in hepatic tissues and necrotic changes as shown in Fig. (3 and 4), while, the heart showed leucocytic inflammatory cell infiltration inbetween the vascular and degenerated myocardial bundles.

The histopathological changes were nearly similar to those obtained by Maronpot et al. (1999) and Percy and Barthold (2001) who studied the pathogenesis of Salmonella typhimurium in rats after injection of Bacilli and invasion to general 
circulation producing bacteremia and invasion to liver and heart leading to previous pathological changes.

The control negative group did not show any pathological changes in liver or heart, So it could be concluded that, aloe extract had significant anti-microbial activity against Salmonella typhimurium. So, it could be used as ration supplementation to control microbial diseases.

Table 1. Effect of aloe extract supplementation to ration of rats experimentally infected with Salmonella typhimurium

\begin{tabular}{|c|c|c|c|c|c|c|}
\hline $\begin{array}{l}\text { Groups } \\
\text { of rats }\end{array}$ & $\begin{array}{l}\text { No. of dead } \\
\text { rats/Total no. } \\
\text { of rats }\end{array}$ & $\begin{array}{l}\text { Mean } \\
\text { death } \\
\text { time } \\
\text { (days) }\end{array}$ & $\begin{array}{c}\text { Mortality } \\
\text { rate }\end{array}$ & $\begin{array}{l}\text { No. of survived } \\
\text { rats/Total No. } \\
\text { of rats }\end{array}$ & Survival \% & $\begin{array}{l}\text { Lesion score in } \\
\text { heart and liver }\end{array}$ \\
\hline (1) & $4 / 50$ & 7 & $8 \%$ & $46 / 50$ & $92 \%$ & $\begin{array}{c}+ \\
\text { (Slight } \\
\text { congestion) }\end{array}$ \\
\hline (2) & $40 / 50$ & 3 & $80 \%$ & $10 / 50$ & $20 \%$ & $\begin{array}{c}c++ \\
\text { (Severe } \\
\text { congestion and } \\
\text { petechial } \\
\text { hemorrhage) }\end{array}$ \\
\hline (3) & $0 / 50$ & - & $0 \%$ & $50 / 50$ & $100 \%$ & - \\
\hline
\end{tabular}

Group (1): Fed on ration supplemented with aloe extract at rate of concentration of $2.5 \%$ and infected with Salmonella typhimurium

Group (2): Fed on ration without aloe extract and infected with Salmonella typhimurium.

Group (3): Fed on ration without aloe extract and not-infected with Salmonella typhimurium. 
Fig. 1. Heart of rat that had aloe extract in ration and inoculated (I/P) by Salmonella typhimurium showing few necrotic changes ( $\mathrm{H} \& \mathrm{E}, \mathrm{x} 40)$

Fig. 2. Liver of rat that had aloe extract in ration and inoculated (I/P) by Salmonella typhimurium showing few cells infiltration and less necrotic changes $(H \& E, x 40)$ 
Fig. 3. Liver of rat that not had aloes extract in ration and inoculated (I/P) by Salmonella typhimurium showing mature and premature leucocytic cells infiltration inbetween hepatic tissues ( $H \& E, x 160$ )

Fig. 4. Liver of rat that not had aloes extract in ration and inoculated (I/P) by Salmonella typhimurium showing hepatocellular necrosis and the mononuclear cells infiltration $(H \& E, x 40)$ 
Fig. 5. Heart of rat that not had aloes extract in ration and inoculated (I/P) by Salmonella typhimurium showing leucocytic cells infiltration in-between the degenerated myocardial bundles ( $\mathrm{H} \& \mathrm{E}, \mathrm{x} 40)$

Fig. 6. Heart of rat that not had aloes extract in ration and inoculated $(I / P)$ by Salmonella typhimurium showing hyperemic myocardial blood vessels $(H \& E, x 40)$ 


\section{REFERENCES}

1. Aisha, M.F. 1987. Effect of watery extracts of some plants on some fungi. M.V.Sc., Pharmacy, Cairo Univ.

2. Bancroft, D.J., C.H. Cook, R.W. Storling and D.R. Tuner. 1994. Manual of histologic techniques and their diagnostic application. Churchill, Livingstone, Edinburgh.

3. Benirsckle, K.F., F.M. Garver and T.C. Jonon. 1978. Pathology of laboratory animals. 2 Vol. Springerverlage, New York.

4. Forbes, B.A.D., F. Sohu and K.S. Weissfield. 1998. Baily and Scotts Diagnostic Microbiology. Mosby St. Louis.

5. Harborne, J.B., H. Boxter and G.P. Moss. 1999. Phytochemical dictionary. Handbook of Bioactive compounds from plates. $2^{\text {nd }}$ Ed. London, UK.

6. Harkness, J.E. and J.E. Wagner 1995. The biology and medicine rabbits and rodents. $4^{\text {th }}$ Ed. Philadelphia, Lea and Febiger.

7. Hassan, A.A., M.M. El-Shorbagy, A.M. El-Barawy and A. Manal. 2008. Study the availability of using Buckthorn (RHaMnuscathartica) plant extract in laboratory control of some bacterial and fungal diseases. Minufiya Vet. J., 5 (1): 27-39.

8. James, G.F., C.A. Lyne, M.I. Frobline and W.Q. Fred 2002. Laboratory animal medicine. $2^{\text {nd }}$ Ed. Academic Press, London, New York.

9. Laurnert, E. 1981. Edible and medicinal plants of Britain and northern Europe. Hamlyn, London, New Yorkm Sydney, Toronto.

10. Moronpot, R.R., C.A. Boorman and B. Gual. 1999. Pathology of mouse. Coche River Press, Vienna, Illions.

11. Mueller, S.O., M. Schmitt, W. Dehot, H. Stopper, J. Schiatter and P.L. Schreier. 1999. Occurrence of modin and liquors genototoxicity and antigenotoxicity of the orthraquinones and of the whole plants. Food Them. Toxicology, 37: 481-491.

12. Percy, D.H. and S.W. Barthold. 2001. Pathology of laboratory rodents and rabbits. $2^{\text {nd }} E d$. Iowa State Univ. Press, Ames.

13. Rofaiil, S.K. 2001. The role of pathogenic and commensal bacterial in Swiss mice with special reference to stress factors. Ph.D. Thesis, Microbiology, Fac. Vet. Med., Alex. Univ.

14. Rofaiil, S.K. 2007. Studies on some additives for reducing some enteric bacteria infection in Swiss mice. J. Egypt. Vet. Med. Assoc., 67 (1): 233-239.

15. Rofaiil, S.K. and A.M. Daoud. 2005. Study on the effect of Nigella sativa supplementation on the growth rate performance and experimental infection by Salmonella typhimurium in Swiss mice. J. Agric. Res., 83 (2): 947-955. 


\section{دراسات على بعض مستخلصات النباتات الطبية كمنشط مناعى فى الجرذان المعدية تجريبياً بالسالمونيلا تيفيميوريوم}

2

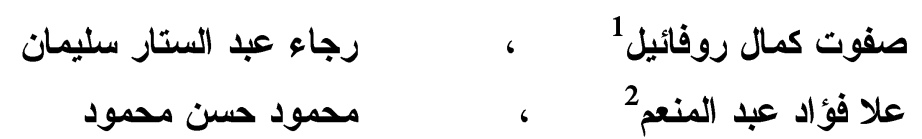

ا ـ معه بحوث الأمصال و اللقاحات البيطرية - مركز البحوث الزراعية - وزارة الزراعة - الدقى - الجيزة

r . معطج بحوث صحة الحبوان - مركز البحوث الزراعية - وزارة الزراعة - الدقى - الجبزة

أجريت هذه الدراسة لمعرفة التأثير الوقائى لمستخلص نبات الصبار على الجرذان المعدية

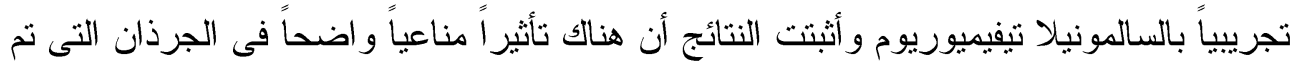
عدو اها بالسالمونيلا تيفيميوريوم سبق معالجتها بخلاصدة الصبار فى العليقة حيث كانت نسبة الجرذان التى لم تتفق ولم تتأثز بالعدوى هى 92\% بالميوريوم بالمقارنة بالمجموعة الغير معالجة النى كانت فيها نسبة

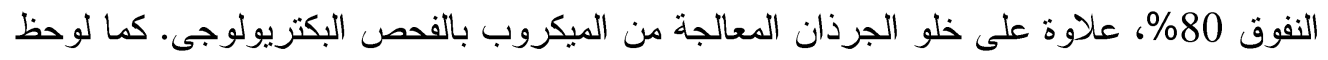

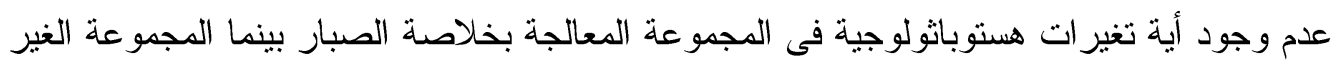
معالجة بتلك الخلاصة ثبت وجود تغيرات و اضحة فى الكبد وهى عبارة عن تتكرز فى الخلايا

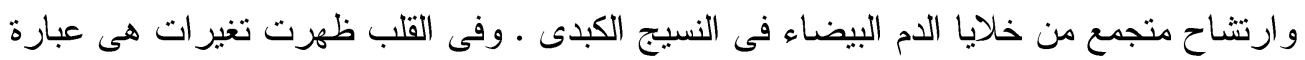

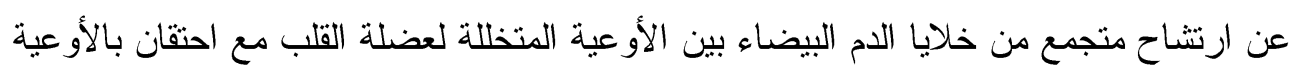
الدموية. 